\title{
AKHLAK TERCELA
}

\author{
Aris Alfarizi \\ UIN Sultan Maulana Hasanudin Banten \\ arisalfarizi8373@gmail.com
}

\begin{abstract}
In the religion of Islam, chastity or conduct occupy a pivotal position, morality has become a pillar above the other pillars. Moral issues have always been associated with the social issues of society, since morals became a symbol of the civilization of a nation. We have seen much of the past generation today more than ever before about how to apply good conduct in a day-to-day life-day. Conduct or morals involve matters relating to good deeds, bad, right and wrong in the actions of a person whose inspiration stems from the qur 'an and the hadis of the prophet saw. This method of writing was the lebrary riseach method collected from preexisting words. As for the results of this writing it indicates that chastity is essential to everyday life, conduct becomes an important capital in social life. The wholesome revival of community life can begin with continued education of breeding, example, observation, and example, building into character.
\end{abstract}

\begin{abstract}
Abstrak
Dalam agama islam, akhlak atau tingkah laku menempati posisi yang sangat penting, Akhlak telah menjadi pilar di atas pilar lainnya. Permasalahan akhlak selalu dikaitkan dengan persoalan sosial masyarakat, karena akhlak menjadi simbol bagi peradaban suatu bangsa. Sudah banyak kita lihat bahwa generasi di zaman sekarang ini sudah sangat memperihatinkan tentang bagaimana cara menerapkan tingkah laku yang baik dalam kehidupaan sehari - hari. Tingkah laku atau akhlak menyangkut hal yang berhubungan dengan perbuatan baik, buruk, benar dan salah dalam tindakan seseorang manusia yang panutannya bersumber dari Al-Qur'an dan Hadis Rasulullah saw. Metode penulisan ini adalah dengan metode Lebrary Riseach dikumpulkan dari katakata yang sudah ada. Adapun hasil dari tulisan ini menunjukkan bahwa akhlak sangat
\end{abstract}


penting dalam kehidupan sehari-hari,tingkah laku menjadi modal penting dalam kehidupan bermasyarakat. Terealisasinya akhlak yang baik dalam kehidupan bermasyarakat dapat diawali dengan pengajaran seterusnya dilanjutkan dengan pendidikan pembiasaan, keteladanan, pengamalan, dibarengi contoh, serta penjelasan, pembinaan hingga akhirnya menjadi karakter.

Kata kunci : Akhlak tercela, karakter 


\section{Pendahuluan}

Kehadiran islam dimuka bumi sebagai pedoman hidup manusia dan untuk memberikan solusi yang tegas terhadap berbagai persoalan kemanusiaan. Salah satu persoalan kemanusiaan yang perlu mendapat perhatian besar dari umat islam adalah persoalaan akhlak. Akhlak adalah puncak keberagamaan seorang muslim. Hal ini sejalam dengan hadist Nabi SAW Yang mengatakan bahwa beliau di utus ke dunia tidak lain adalah untuk menyempurnakan akhlak. Berislam yang tidak membuahkan akhlak adalah sesuatu yang sia-sia. Akhlak atau tingkah laku menjadi sesuatu yang sangat sentral yang harus di miliki oleh semua orang dalam menapaki kehidupannya. Masih banyak sekali orang-orang yang belum mengetahui tentang pentingnya akhlak di dalam kehidupan, sehingga masih banyak sekali orang-orang yang memiliki akhlak yang tidak baik (Akhlak mazmumah). Akhlak yang baik merupakan salah satu modal kebahagiaan manusia di dunia. Kedudukan akhlak di dalam islam sangat tinggi. Nabi saw pernah di tanya tentang amalan yang paling banyak memasukan seseorang kedalam syurga.

Beliau mengatakan :

$$
\text { تقوى الله وحسن الخلق }
$$

“ Bertaqwa kepada allah dan berakhlak yang baik " (HR. Ahmad,Tirmidzi,Ibnu majah).

Sedangkan akhlak yang tidak baik akan membawa diri kita pada kesusahan dan kesulitan dalam segala aspek kehidupan. Akhlak pada dasarnya melekat dalam diri seseorang, telah bersatu dengan perilaku atau perbuatan. Jika perilaku yang melekat itu buruk, maka disebut akhlak yang buruk atau akhlak mazmumah. Sebaliknya, apabila perilaku tersebut baik disebut akhlak mahmudah. Oleh karena itu untuk menciptakan dan memiliki akhlak yang baik pada diri kita perlu adanya pendidkan sejak dini tentang bagaimana bertingkah laku yang baik terutama terhadap Allah, sesama manusia, ataupun terhadap makhluk allah lainnya. 


\section{Pembahasaan}

\section{Pengertian akhlak}

Dalam kamus besar Bahasa Indonesia. Kata Akhlak diartikan sebagai budi pekerti atau kelakuan. Kata akhlak walaupum terambil dari Bahasa arab (yang bisa berartikan tabiat, kebiasaan, bahkan agama), namun kata seperti itu tidak di temukan dalam AlQuran. ${ }^{1}$ Dalam al-munjid kata akhlak adalah kata jamak yang berarti "Budi pekerti, perangai, tingkah laku”. Di dalam al-Mujam al-Wasit disebutkan akhlak adalah sifat yang tertanam di dalam jiwa, yang dengannya lahirlah macam - macam perbuatan baik atau buruk tanpa membutuhkan pemikiran atau pertimbangan. ${ }^{2}$

Ibnu Maskawih sebagai pakar dibidang akhlak mengatakan bahwa akhlak adalah sifat tertanam did dalam jiwa yang mendorongnya untuk melakukan tanpa membutuhkan pemikiran atau pertimbangan. Selanjutnya Hujjatul Islam (pembela islam) Imam alGhazali dengan penjelasan yang sedikit luas mengatakan akhlak adalah sifat yang tertanam di dalam jiwa yang menimbulkan bermacam-macam perbuatan dengan mudah tanpa memerlukan pemikiran atau pertimbangan. ${ }^{3}$

Dalam ensiklopedia islam dikatakan bahwa akhlak adalah suatu keadaan yang melekat pada jiwa manusia yang dari padanya lahir perbuatan-perbuatan dengan mudah tanpa melalui proses pemikiran, pertimbangan dan penelitian. ${ }^{4}$

Dari pengertian dia atas terdapat kesamaan, bahwasanya akhlak itu merupakan perbuatan yang berpangkal pada hati atau atas kesadaran jiwanya tanpa memerlukan pertimbangan dan tanpa ada unsur pemaksaan, kemudian diwujudkan dalam perbuatan yang berulang-ulang sehingga menjadi adat dan akhirnya menjadi sifat. Sifat adalah sebagian dari keperibadian. Sehingga sulit di ubah, karena telah telah tertanam dalam keperibadiannya. Jika keadaan (hal) tersebut melahirkan perbuatan terpuji menurut pandangan syariat isalm dan akal pikiran, disebut akhlakul karimah ( baik ). Jika

\footnotetext{
${ }^{1}$ Kamus Besar Bahasa Indonesia,

${ }^{2}$ Hidayati,Heny Narendrany, Pengukuran akhlakul karimah mahasiswa, UIN Press dan center for Quality Develoment And Assurance - Lembaga Peningkatan Dan Jaminan Mutu (LPJM) UIN Syarif hidayatullah Jakarta, Jakarta, 2009, hlm 7.

${ }^{3}$ Ibid

${ }^{4}$ Ibid
} 
perbuatan-perbuatan yang timbul tidak baik maka dinamakan akhlakul mazmumah ( buruk ). ${ }^{5}$

Pada dasarnya manusia memiliki kedua potensi baik dan buruk. Sebagaimana dalam Al-Quran :

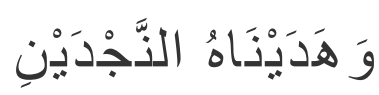

Artinya : “ Maka kami telah memberikan petunjuk (kepada) nya (manusia) dua jalan mendaki (Baik dan buruk) ". ( al-Balad: 10 ).

Dalam kaitan pengertian akhlak ini, Ulil Amri Syafri mengutip pendapat Nashiruddin Abdullah, yang menyatakan bahwa, secara garis besar dikenal dua jenis akhlak; yaitu akhlaq al karimah (akhlak terpuji), akhlak yang baik dan benar menurut syariat Islam, dan akhlaq al mazmumah (akhlak tercela), akhlak yang tidak baik dan tidak benar menurut syariat Islam. Akhlak yang baik dilahirkan oleh sifat-sifat yang baik pula, demikian sebaliknya akhlak yang buruk terlahir dari sifat yang buruk. Sedangkan yang dimaksud dengan akhlaq al mazmumah adalah perbuatan atau perkataan yang mungkar, serta sikap dan perbuatan yang tidak sesuai dengan syariat Allah, baik itu perintah maupun larangan-Nya, dan tidak sesuai dengan akal dan fitrah yang sehat. ${ }^{6}$

\section{Metode Pembinaan Akhlak}

Pembinaan akhlak merupakan tumpuan perhatian pertama dalam islam. Karena begitu pentingnya akhlak bagi kehidupan umat manusia, oleh karena itu Allah SWT. Mengutus rasulnya Muhammad SAW salah satu tujuaannya adalah untuk menyempurnakan akhlak manusia. Sebagaimana Rasulallah SAW bersabda :

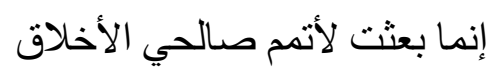

"Sesungguhnya saya diutus untuk menyempurnakan akhlak yang baik."

( HR. abu Hurairah07/273) ${ }^{7}$

\footnotetext{
${ }^{5}$ Ahmad, Imam S, Tuntunan Akhlakul Karimah, Lekdis, Jakarta, 2005

${ }^{6}$ MODEL PENDIDIKAN AKHLAK DI MTs. AL-WASLIYAH 63 PUNGGULAN AIR JOMAN KABUPATEN ASAHAN, Miftah Anugrah Nasution, Syaukani, Mesiono ${ }^{7}$ https://carihadis.com/Shahih_Adabul_Mufrad_Terjemah/=menyempurnakan\%20akhlak
} 
Perhatian islam demikian dalam pembinaan akhlak ini dapat pula dilihat dari perhatian islam terhadap pembinaan jiwa yang harus daripada pembinaan fisik, karena dari jiwa yang baik inilah yang akan menghasilkan kebaikan dan kebahagiaan pada seluruh kehidupan manusia, lahir dan batin. Perhatiaan islam dalam pembinaan akhlak selanjutnya dapat di analisis pada muatan akhlak yang terdapat pada seluruh aspek ajaran islam. Ajaran amal shaleh dan perbuatan terpuji. Iman yang tidak disertai amal shaleh dinilai sebagai iman palsu,bahkan dianggap sebhagai kemunafikan. ${ }^{8}$

Ada beberapa metode pembinaan akhlak yang dapat dilakukan sesuai dengan perspektif islam yaitu sebagai berikut. Pertama, Metode uswah, yaitu sesuatu yang pantas untuk di ikuti,karena mengandung nilai-nilai kemanusiaan. Manusia teladan yang harus di contoh adalah Rasulallah SAW. Sebagaimana firman Allah SWt dalam surat Al-Ahzab: 21 yang artinya " sesungguhnya terdapat dari diri Rasulallah itu,teladan yang baik bagimu. ". Jadi sikap dan perilaku yang harus di contoh adalah perilaku Rasulallah SAW, karena telah teruji dan di akui oleh Allah SWT. Aplikasi metode teladan, diantaranya adalah tidak menjelek-jelekan seseorang, membantu orang, dan lain lain. ${ }^{9}$ Kedua,Metode Ta'widiyah (pembiasaan). Secara etimologi pembiasaan asal katanya adalah biasa. Dalam kamus umum bahasa indonesia, biasa artinya lazim atau umum; seperti sedia kala, sudah merupakan hal yang tidak terpisahkan dalam kehidupan sehari-hari. Muhammad Mursyi dalam bukunya Seni Mendidik Anak, menyampaikan nasehat imam al-Gazaliı: seorang anak adalan amanah (titipan) bagi orang tuanya hatinya sangat bersih bagaikan mutiara, jika dibiasakan dan diajarkan sesuatu kebaikan, maka ia akan tumbuh dewasa dengan tetap melakukan kebaikan tersebut, sehingga ia mendapatkan kebahagiaan di dunia dan akhirat." Dalam ilmu jiwa perkembangan, dikenal teori konvergensi, dimana peribadi dapat dibentuk oleh lingkungannya, dengan mengembangkan potensi dasar yang ada padanya. Salah satu cara yang dapat dilakukan untuk mengembangkan potensi dasar tersebut adalah melalui kebiasaan yang baik. Oleh karena itu, kebiasaan yang baik dapat menempa peribadi yang berahlak mulia. Seperti; terbiasa dalam keadaan berwudhu, terbisa tidur tidak terlalu larut malam dan bangunnya tidak kesiangan, terbiasa membaca AL-Qur'an

${ }^{8}$ Zulkifli,MA Pengantar Studi Islam , Bias cemerlang, Tangerang, 2006.

${ }^{9}$ Zuhairi, Dkk. 1983. Metodik khusus Pendidikan agama. Surabaya : Usaha nasional 
dan Asma'ul husna, shalat berjama:ah di masjid, terbiasa berpuasa sekali sebulan, terbiasa makan dengan tangan kanan, dan lain- lain sebagainya. ${ }^{10}$ Ketiga Metode Mau'izah (nasehat), yaitu kata mai'izah berasal dari kata wa'zhu, yang berarti nasehat yang terpuji memotivasi untuk melaksanakannya dengan perkataan yang lembut. Allah berfirman dalam surah Al-Baqarah: 232, yang artinya,.... itulah yang dinasehatkan kepada orang-orang vang beriman di antara kalian, yang beriman kepada Allah dan hari kemudian" Sebagai contoh metode nasehat yang baik yaitu; nasehat dengan argumen logika, nasehat tentang keuniversalan islam, nasehat yang berwibawa, nasehat dari aspek hukum, nasehat tentang amar ma'ruf nahi mungkar, nasehat tentang amal ibadah, dan lain-lain. ${ }^{11}$ Keempat, Metode Qishah (cerita), yang mengandung arti, sutu cara dalam menyampaikan materi pelajaran, dengan menuturkan secara kronologis, tentang bagimana terjadinya sesuatu hal, baik yang sebenarnya terjadi, ataupun hanya rekaan saja.Dalam pendidikan islam, certera yang bersumber dari Al-Qur'an dan hadits merupakan metode pendidikan yang sangat penting, cerita dalam Al-Qur'an dan Hadits, selalu memikat dan menyentuh perasaan dan mendidik perasaan keimanan, contohnya, surah Yusuf, Bani Israail, dan lain- lain. Kelima Metode Amtsal (perumpamaan), yaitu metode yang banyak dipergunakan dalam Al-Qur'an dan Al-hadits untuk mewujudkan ahklak mulia. Allah berfirman dalam surah Al-Baqarah : 17 yang artinya; “ perumpamaan mereka adalah Seperti orang yang menyalakan api.. dalam beberapa literatur islam, ditemukan banyak sekali perumpamaan, Seperti mengumpamakan orang yang lemah laksana kupu-Kupu, orang yang tinggi seperti jerapah, orang yang berani Pendidik harus seperti gajah, orang yang kurus seperti tongkat, dan orang yang ikut-ikutan seperti beo, dan lain-lain. ${ }^{12}$ Keenam, Metode Tsawab (ganjaran). Sebagaiamana yang telah di utarakan Armai Arief dalam bukunya, Pengantar IImu dan Metodologi Pendidikan Islam, menjelaskan pengertian tsawab itu, sebagai: "hadiah; hukum. Metode ini juga penting dalam pembinaan ahklak, karena hadiah dan hukuman sama artinya dengan reward and punisment dalam pendidikan Barat. Hadiah bisa menjadi dorongan spiritual dalam bersikap baik, sedangkan hukuman dapat menjadi

10 Ibid

11 Ibid

12 Ibid 
remote control dari perbuatan tidak terpuji. Misalkan memanggil dengan panggilan kesayangan, memberikan pujian, memberikan maaf atas kesalahan mereka, mengeluarkan perkataan yang baik, bermain atau bercanda, manyambutnya dengan ramah, menelponnya kalau perlu, dan lain-lain. Sedangkan metode aplikasi ganjaran yang berbentuk hukuman, di antaranya, pandangan yang munis, memuji orang lain di hadapannya, tidak mempedulikannya, memberikan ancaman yang positif, dan menjewanya sebagi alternatif terakhir. Hadits yang di riwayatkan oleh Imam Nawawi dari Abdullah bin Basr al-Mani, ia berkata : "aku telah diutus oleh ibuku, dengan membawa beberapa biji anggur untuk di sampaikan kepada Rasulullah, kemudian aku memakannya sebelum aku sampikan kepada Beliau dan ketika aku mendatangi Rasulullah, beliau menjewer telingaku sambil berseru: "wahai penipu". Dari hadits diatas, dapat dikemukakan, bahwa menjewer telinga anak boleh-boleh saja. Asal tidak menyakiti. ${ }^{13}$

\section{Akhlak tercela}

Perilaku tercela adalah sifat yang sangat merugikan diri sendiri maupun orang lain, dalam ajaran Islam perbuatan tersebut sangat bertentangan. Perilaku tercela ada 5 yaitu: ananiyah, gadab, hasad, gibah, dan namimah. ${ }^{14}$ Yang pertama Ananiyah ini adalah karakter alami yang ada pada diri setiap insan apabila ia diperlakukan sesuai dengan batas koridor yang ada. Namun apabila melampaui kadarnya, sehingga menjelma menjadi sebuah sikap jumawa, sombong, meremehkan orang lain, menganggap orang lain itu kecil, menyepelekan pendapat orang lain, serta senantiasa berusaha untuk menguasai orang lain, maka ini adalah bahaya laten serta penyakit yang membinasakan. Maka dari itu seorang manusia yang terkena virus ini tidak akan mau mengakui kesalahan. Dan ia senantiasa menyangka dirinya selalu benar, merasa bersih dari kesalahan dan ketergelinciran. Ia tidak memahami bahwa mengakui kesalahan itu sebagai bentuk memuliakan akal manusia. ${ }^{15}$ Kedua, ghadab harfiah berarti "marah" atau "pemarah", atau disebut juga dengan temperamental. Ghadab dalam arti pemarah merupakan salah satu sifat negatif. Bila ditinjau definisi marah merupakan suatu reaksi

\footnotetext{
${ }^{13} \mathrm{lbid}$

${ }^{14}$ http://e-repository.perpus.iainsalatiga.ac.id/4054/1/revisi\%20bagus\%20banget\%20I

${ }^{15}$ Idib
} 
terhadap hambatan yang menjadi sebab gagalnya suatu usaha atau suatu perbuatan dalam mencapai suatu tujuan tertentu. Dalam bahasa Indonesia "amarah" sama dengan kata "marah", yakni suatu keadaan atau sifat dari seseorang pada saat ia merasakan tidak senang atau tidak merasa nyaman karena sedang smenghadapi suatu hambatan atau diperlakukan tidak sepantasnya, dapat juga bermakna gusar atau berang. ${ }^{16}$ Ketiga, Hasad Dalam kamus al-'Ain disebutkan lafadz hasad adalah mashdar dari fi' il hasada yaḥsudu hasadan. ${ }^{17}$ Dalam kamus Lisân al-'Arab disebutkan asal kata hasad adalah Qasyr (lapisan kulit luar), Ibn Mandzûr mengutip perkataan al-Azharî dari Ibn alA'râbî (w. 543 H) bahwa hasad menguliti hati seperti kutu menguliti kulit kemudian menghisap darahnya. Hasad yaitu ketika seseorang melihat nikmat yang dimiliki saudaranya, ia berharap nikmat tersebut hilang dari saudaranya tersebut dan menjadi miliknya seorang. Sedangkan al-Ghabthu yaitu harapan seseorang memiliki nikmat seperti yang dimiliki saudaranya tetapi tidak berharap nikmat tersebut hilang dari saudaranya. ${ }^{18}$ Menurut al-Ghazâlî (450-505 H/1058-1111 M), dalam semua keadaan hukum hasad adalah haram, kecuali hasad terhadap nikmat yang diperoleh fajir (yang hanyut dalam kemaksiatan) dan orang kafir yang mana nikmat tersebut digunakan untuk menyebar fitnah, menciptakan permusuhan dan menyakiti makhluk. Kebencian terhadap nikmat yang dimiliki fajir dan kafir serta keinginan agar nikmat tersebut hilang dari mereka tidaklah membawa mudharat, karena kita tidak menginginkan nikmat tersebut hilang dari segi bendanya, akan tetapi dari segi nikmat tersebut digunakan sebagai alat untuk kerusakan, andaikan nikmat tersebut bukanlah alat untuk kerusakan tentulah kita tidak menginginkan nikmat tersebut. ${ }^{19}$ Keempat, Ghibah menurut bahasa berarti umpatan, fitnah dan gunjingan. ${ }^{20}$ Kemudian kata "umpatan" dalam kamus bahasa Indonesia dapat diartikan sebagai perkataan yang memburukburukkan orang lain. ${ }^{21}$ Dapat pula diartikan penggunjingan yang diidentikkan dengan

\footnotetext{
${ }^{16}$ Tim penysun kamus besar bahasa Indonesia, Kamus Besar Bahasa Indonesia, (Jakarta : Balai Pustaka, 1990$), 26$.

${ }^{17}$ Khalîl Ibn Aḥmad, Kitâb al-'Ain, Tahqîq: 'Abd al-Hamîd Hindâwî, Juz 1, (Beirut: Dâr alKutub al-'Ilmiyah, 2003), Cet.

1, h. 315

18 Ibn Mandzur, Lisân al-'Arab, (Kairo: Dâr al-Ma'ârif, t.t.), Jilid 2, h. 868

${ }^{19}$ Abû Hâmid al-Ghazâlî, Iṇyâ' 'Ulûm ad-Dîn, Tahnqîq: Asy-Syahnât ath-Thahân dan 'Abdullâh alMinsyâwî, Jilid 3, (Manshûrah: Maktabah al-Îmân, 1996), Cet. 1, h. 268

${ }^{20}$ Ahmad Warson Munawir, al-Munawwir; Kamus Arab Indonesia (Cet. IV; Yogyakarta: pustaka rogressif, 1997), h. 1025

${ }^{21}$ WJS. Poerwadarminta, Kamus Umum Bahasa Indonesia (Cet. VII; Jakarta: PN. Balai Pustaka, 1985 ), h. 1125.
} 
kata gosip, yaitu kata negatif tentang seseorang. ${ }^{22}$ Gibah diidentikkan dengan umpatan, pergunjingan dan gosip. Ghibah adalah bahasa Arab dan telah populer di kalangan masyarakat muslim Indonesia. Kata ini berasal dari tiga huruf yaitu: yang mempunyai arti dasar sesuatu yang tersembunyi dari mata. ${ }^{23}$ Dari kata ini, terciptalah kata al-ghaib yang berarti sesuatu yang tidak nampak, dan al-ghibah. merupakan istilah yang menunjukkan kepada hal yang membicarakan tentang keburukan atau aib seseorang yang tidak ada. ${ }^{24}$ Dan orang yang dibicarakan tidak senang dan tidak ada di tempat pembicaraan berlansung. Sesuai batasan yang diberikan oleh hadis nabi seperti yang telah disebutkan. Informasi yang membicarakan tentang gosip seseorang dapat dikategorikan dalam gibah, khususnya yang berhubungan dengan masalah privatisasi seseorang; pribadi dan keluarganya, serta semua yang berhubungan dengan dirinya, seperti agama, harta, keturunan, bahkan termasuk gibah pembicaraan tentang aib antara kelompok masyarakat. Pengertian di atas, dapat disimpulkan bahwa sesuatu obrolan dapat dikatakan gibah bila orang yang dibicarakan tidak ada dan obyek pembicaraan tentang kekurangan atau aib seseorang dan orang tersebut tidak rela dengan pembicaraan itu. Kelima, namimah(adu domba) adalah menyebarkan omongan kepada orang banyak yang berisi provokasi dan niat jahat. ${ }^{25}$ Menurut Imam Abu Zakaria Yahya bin Syaraf an-Nawawi,, definisi namîmah adalah merekayasa omongan, menghasut, memprovokasi untuk menghancurkan manusia. ${ }^{26}$

Adapun untuk lebih memahami perihal akhlak tercela mari kita kaji lebih dalam mengenai hadis-hadisnya yang berhubungan dengan akhlak tercela tersebut.

عَنْ أَبِي هُرَيْرَةَ رَضِيَ اللهُ عَنْهُ قَالَ :قَالَ رَسُوْلُ اللهِ صلى الله عليه وسلم :لاَ تَحَاسَدُوا وَلاَ تَنَاجَشُوا

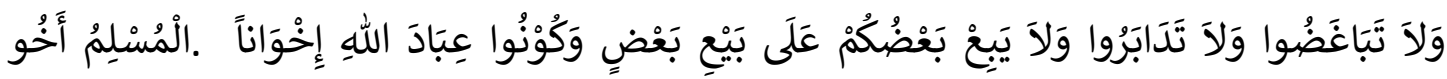

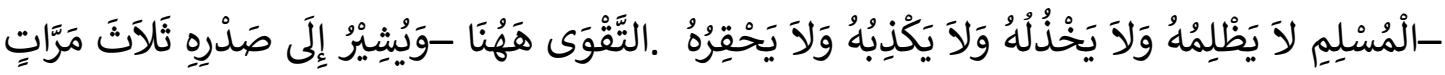

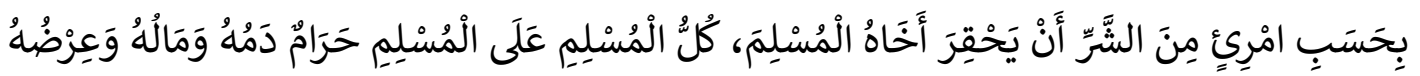

22 WJS. Poerwadarminta, Kamus Umum Bahasa Indonesia

${ }^{23}$ Abu al-Husein Ahmad ibn Faris ibn Zakariya, Mu'jam Maqayis al-Lugah (Cet. I; Beirut: Dar al Fikr, 1994), h. 818.

${ }^{24}$ Jamal al-Din Muhammad ibn Makram al-Mansur, Lisan al-'Arab, jilid 5 (Cairo: Dar alMa'arif, t.th.), h. 3323.

${ }^{25}$ Wahbah Az-Zuhaili, Ensiklopedia Akhlak Muslim: Berakhlak dalam Bermasyarakat, (Jakarta: .Mizan Publika, 2014), h.301.

${ }^{26} \mathrm{lbid}$ 
Dari Abu Hurairah radhiallahuanhu dia berkata : Rasulullah shollallohu 'alaihi wa sallam bersabda : Janganlah kalian saling dengki, saling menipu, saling marah dan saling memutuskan hubungan. Dan janganlah kalian menjual sesuatu yang telah dijual kepada orang lain. Jadilah kalian hamba-hamba Allah yang bersaudara. . Seorang muslim adalah saudara bagi muslim yang lainnya, (dia) tidak menzaliminya dan mengabaikannya, tidak mendustakannya dan tidak menghinanya. Taqwa itu disini (seraya menunjuk dadanya sebanyak tiga kali-). Cukuplah seorang muslim dikatakan buruk jika dia menghina saudaranya yang muslim. Setiap muslim atas muslim yang lain; haram darahnya, hartanya dan kehormatannya “ (Riwayat Muslim)

Pelajaran yang terdapat dalam hadis :

1. Larangan untuk saling dengki .

2. Larangan untuk berbuat keji dan menipu dalam urusan jual beli.

3. Diharamkan untuk memutuskan hubungan terhadap muslim. Sebaliknya harus dijaga persaudaraan dan hak-haknya karena Allah ta'ala.

4. Islam bukan hanya aqidah dan ibadah saja, tetapi juga didalamnya terdapat urusan akhlak dan muamalah.

5. Hati merupakan sumber rasa takut kepada Allah ta'ala.

6. Taqwa merupakan barometer keutamaan dan timbangan seseorang.

7. Islam memerangi semua AKHLAK TERCELA karena hal tersebut berpengaruh negatif dalam masyarakat Islam. ${ }^{27}$

Dari Abu Ad-Darda' 204/270 dari Nabi shallallahu 'alaihi wasallam bersabda,

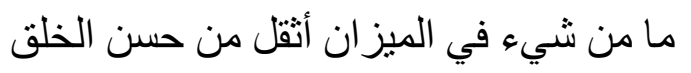

"Tidak ada sesuatu yang lebih berat dalam timbangan daripada akhlak yang baik. ${ }^{28}$

Dari abu Abdullah ibnu Amru berkata,

${ }^{27}$ https://carihadis.com/Arbain_Nawawi_II/=AKHLAK\%20TERCELA

${ }^{28}$ https://carihadis.com/Shahih_Adabul_Mufrad_Terjemah/=menyempurnakan\%20akhlak 


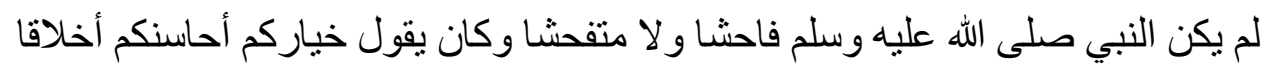

"Nabi shallallahu 'alaihi wasallam bukanlah orang yang keji dan bukan pula orang yang memerintahkan perbuatan keji, dan beliau pernah bersabda, 'Sebaik-baiknya diantara kamu adalah yang terbaik akhlaknya."'29

Dari Amru ibnu Syu'aib, 206/272 dari bapaknya, dari kakeknya, bahwasanya dia mendengar Nabi shallallahu 'alaihi wasallam bersabda, :

$$
\text { أخبركم بأحبكم إلى و أقربكم منى مجلسا يوم القيامةٌ؟ فسكت القوم فأعادها مرتين أو ثلاثا قال القوم }
$$

Saya memberitahu kalian tentang hal yang paling saya cintai dan yang paling dekat diantara kalian tempatnya dengan saya pada hari kiamat?' Lalu kaum (muslimin) terdiam, kemudian Nabi shallallahu 'alaihi wasallam mengulangi kalimat itu dua atau tiga kali, maka kaum (muslimin) berkata, 'Betul, wahai Rasulullah!.' Rasulullah menerangkan, 'Mereka yang paling baik akhlaknya."'30

Dari Abu Hurairah, bahwa Rasulullah shallallahu 'alaihi wasallam bersabda. :

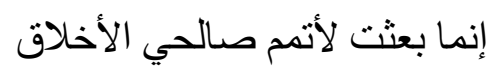

"Sesungguhnya saya diutus untuk menyempurnakan akhlak yang baik. "31

Dari Abdullah ibnu Mas'ud berkata,:

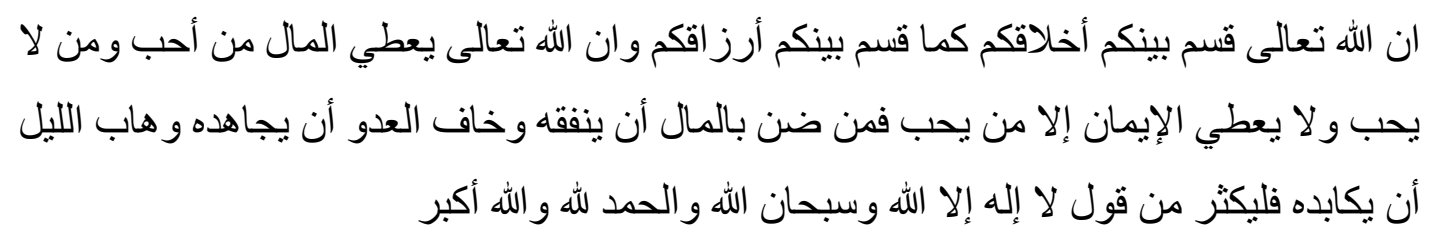

"Sesugguhnya Allah membagi akhlak diantara kalian sebagaimana Allah membagi rezeki diantara kalian dan sesungguhnya Allah Subhanahu wa Ta'ala memberi rezeki

\footnotetext{
${ }^{29}$ Dalam kitab Ash-Shahihah (286). (Bukhari, 78-Kitab Al Adab, 39- Bab Husnul khuluqi wassakha'i wa ma yakrahu minal-bukhli. Muslim, 4- Kitab Fadha^il, 16-Katsratu-hayatihi shallallahu 'alaihi wasallam, hadis 68).

${ }^{30}$ Dalam kitab Ash-Shahihah (792).

${ }^{31}$ Dalam kitab Ash-Shahihah (45)
} 
kepada orang yang dicintai dan orang yang tidak dicintai. Allah juga tidak memberikan iman kecuali kepada orang yang dicintai. Barang siapa yang menjaga hartanya, takut diperangi musuh dan takut menderita karena (angin) malam, maka hendaknya memperbanyak ucapan Laa Ilaha Illallahu (tiada Tuhan kecuali Allah), Subhanallah (Maha Suci Allah), Al Hamdulillah (Segala puji bagi Allah), dan Allahu Akbar (Allah Maha Besar)."32

Menurut Bukhari-Muslim dari hadis 'Aisyah r.a:

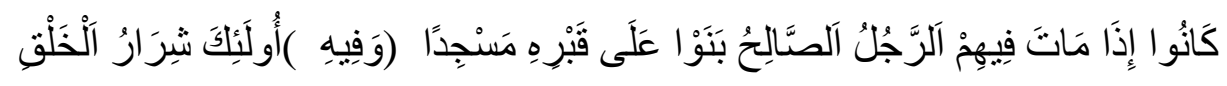

"Apabila ada orang sholeh di antara mereka yang meninggal dunia mereka membangun di atas kuburannya sebuah masjid." Dalam hadis itu disebutkan: "Mereka itu berakhlak buruk."

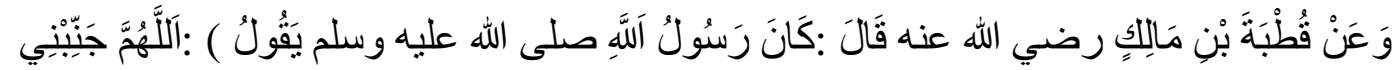

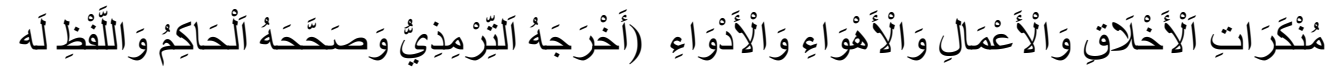

Dari Quthbah Ibnu Malik Radliyallaahu 'anhu bahwa Rasulullah Shallallaahu 'alaihi wa Sallam bersabda: "Ya Allah jauhkanlah diriku dari kejelekan AKHLAK perbuatan hawa nafsu dan penyakit." Riwayat Tirmidzi. Hadis shahih menurut Hakim dan lafadz ini menurut riwayatnya. ${ }^{34}$

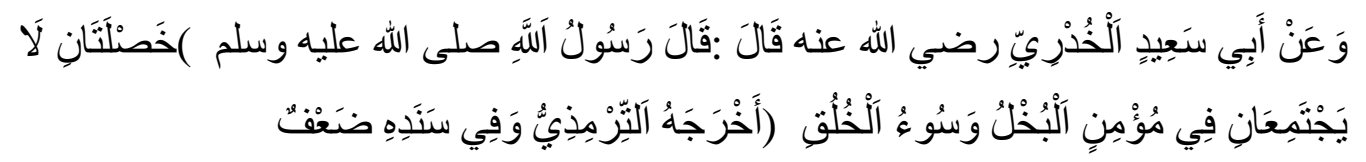

Dari Abu Said al-Khudry Radliyallaahu 'anhu bahwa Rasulullah Shallallaahu 'alaihi wa Sallam bersabda: "Dua sifat jangan sampai berkumpul dalam diri

${ }^{32}$ Dalam kitab Ash-Shahihah (2714)

${ }^{33}$ Bulughul maram No. hadist 265/1597

${ }^{34}$ Bulughul marom No. hadist 1526/1597 
seorang muslim yaitu kikir dan AKHLAK jelek." Riwayat Tirmidzi dan dalam sanadnya ada kelemahan. ${ }^{35}$

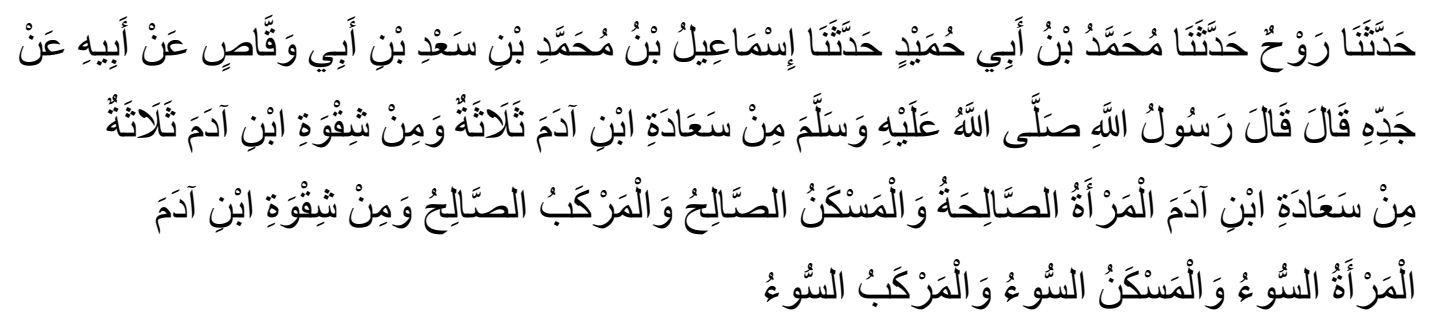

Telah menceritakan kepada kami [Rauh] telah menceritakan kepada kami [Muhammad bin Abu Humaid] telah menceritakan kepada kami [Isma'il bin Muhammad bin Sa'd bin Abu Waqqash] dari [bapaknya] dari [kakeknya] berkata; Rasulullah shallallahu 'alaihi wasallam bersabda: "Tiga indikasi kebahagiaan anak Adam, dan tiga indikasi kesengsaraan anak Adam; indikasi kebahagiaan anak cucu adam adalah istri yang shalehah, tempat tinggal yang baik dan kendaraan yang baik. Sedangkan indikasi kesengsaraan anak Adam adalah istri yang berakhlak buruk, tempat tinggal yang buruk dan kendaraan yang buruk. "36

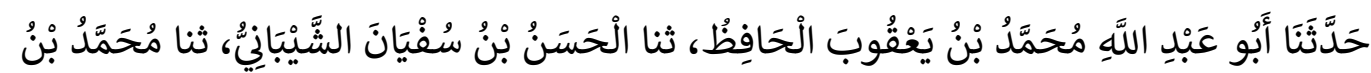

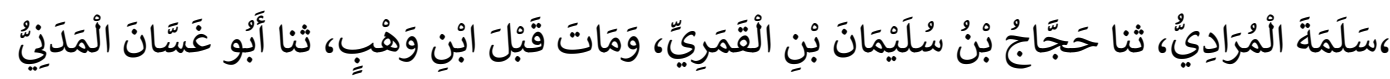

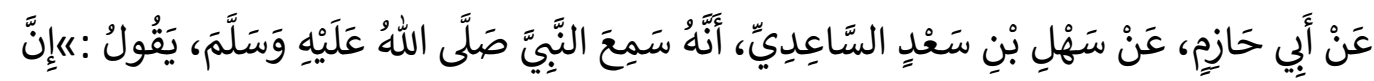

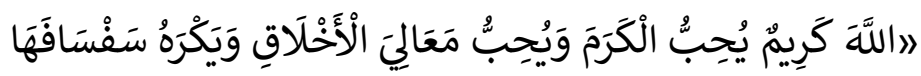

Abu Abdillah Muhammad bin Ya'qub Al Hafizh menceritakan kepada kami, Al Hasan bin Sufyan Asy-Syaibani menceritakan kepada kami, Muhammad bin Salamah Al Muradi menceritakan kepada kami, Hajjaj bin Sulaiman bin Al Qamari - orang yang meninggal sebelum Ibnu Wahab- menceritakan kepada kami, Abu Ghassan Al Madani menceritakan kepada kami dari Abu Hazim, dari Sahi bin Sa'ad As-Sa'idi, bahwa dia pernah mendengar Nabi shallallahu 'alaihi wa sallam bersabda,

\footnotetext{
${ }^{35}$ Bulughul marom No. hadist 1528/1597
}

${ }^{36}$ Musnad ahmad No. Hadist 1368 
"Sesungguhnya Allah Maha Dermawan dan menyukai kedermawanan, menyukai akhlak yang mulia, dan membenci akhlak buruk",37

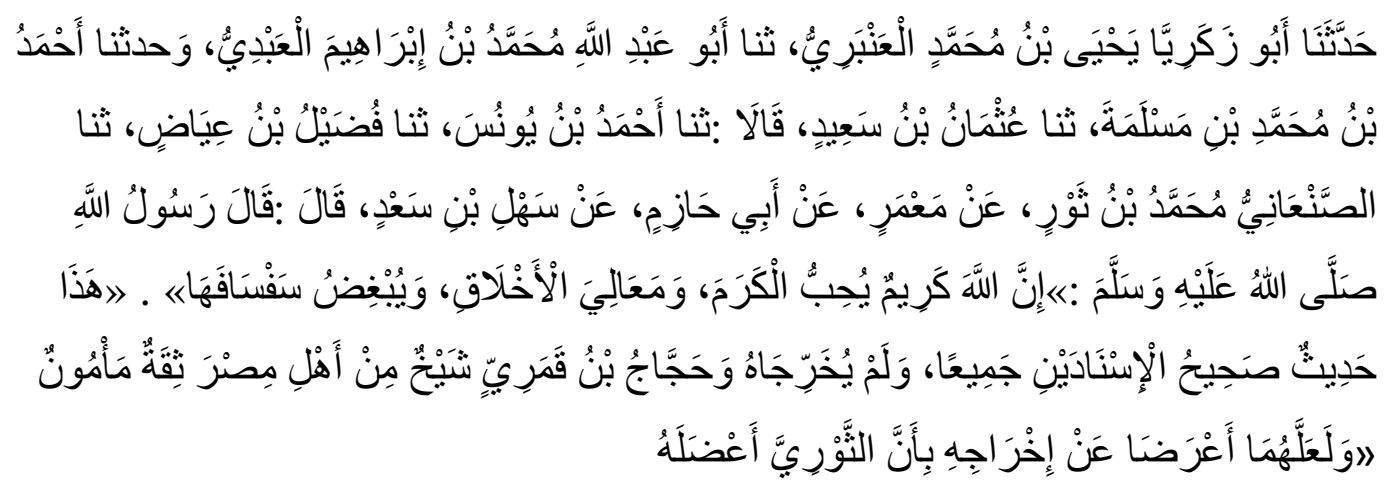

Abu Zakaria Yahya bin Muhammad Al Anbari menceritakan kepada kami, Abu Abdillah Muhammad bin Ibrahim Al Abdi menceritakan kepada kami. Ahmad bin Muhammad bin Maslamah dan Utsman bin Sa'id menceritakan kepada kami, keduanya berkata: Ahmad bin Yunus menceritakan kepada kami, Fudhail bin Iyadh menceritakan kepada kami, Ash-Shan'ani Muhammad bin Tsaur menceritakan kepada kami dari Ma'mar, dari Abu Hazim, dari Sahal bin Sa'ad, dia berkata: Rasulullah shallallahu 'alaihi wa sallam bersabda, "Sesungguhn Allah Maha Pemurah dan menyukai kedermawanan, menyukai akhlak yang mulia, serta membenci akhlak buruk." Kedua sanad hadis ini shahih, tapi Al Bukhari dan Muslim tidak meriwayatkannya. Hajjaj bin Qamari adalah seorang syaikh dari Mesir, seorang periwayat tsiqah ma'mun. Mungkin keduanya enggan meriwayatkannya karena Ats-Tsauri menganggapnya mu'dhal. ${ }^{38}$

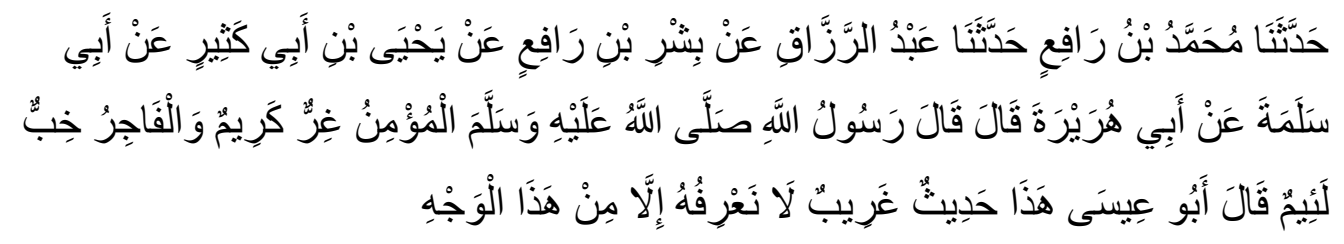

Telah menceritakan kepada kami [Muhammad bin Rafi'], telah menceritakan kepada kami [Abdurrazzaq] dari [Bisyr bin Rafi'] dari [Yahya bin Abu Katsir] dari [Abu

\footnotetext{
${ }^{37}$ Mustadrak Hakim No. Hadist 151/673

${ }^{38}$ Mustadrak hakim No.hadist 152/673
} 
Salamah] dari [Abu Hurairah] ia berkata; Rasulullah shallallahu 'alaihi wasallam bersabda: "Seorang mukmin itu senantiasa berlapang dada dan dermawan, sedangkan seorang fajir itu bakhil dan berakhlak buruk." Abu 'Isa berkata; Ini adalah hadis gharib, tidak kami ketahui kecuali dari jalur ini. ${ }^{39}$

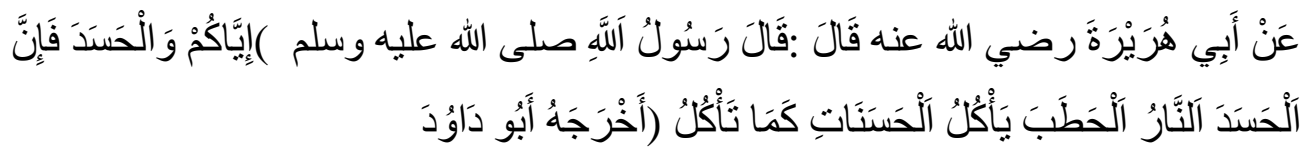

Dari Abu Hurairah Radliyallaahu 'anhu bahwa Rasulullah Shallallaahu 'alaihi wa Sallam bersabda: "Jauhilah sifat hasad karena hasad itu memakan (pahala) kebaikan sebagaimana api memakan kayu bakar." Riwayat Abu Dawud. ${ }^{40}$

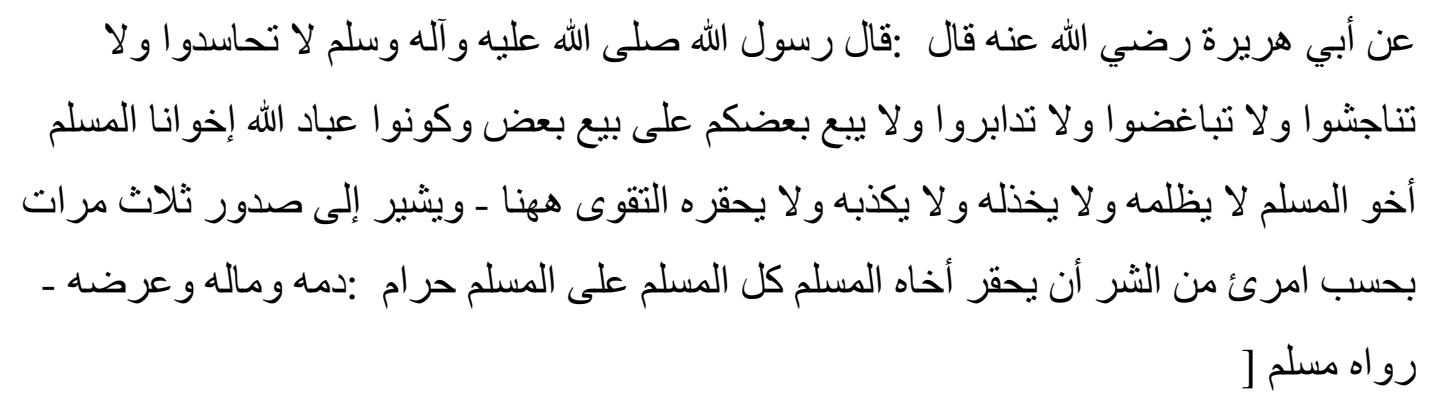

Dari Abu Hurairah rodhiallohu 'anhu berkata, Rasulullah sholallahu 'alaihi wa sallam bersabda, "Janganlah kalian saling dengki, jangan saling menipu, jangan saling membenci, jangan saling membelakangi, dan jangan kalian membeli suatu barang yang (akan) dibeli orang. Jadilah kamu sekalian hamba-hamba Alloh yang bersaudara. Seorang muslim adalah saudara bagi muslim yang lainnya, tidak layak untuk saling menzhalimi, berbohong kepadanya dan acuh kepadanya. Taqwa itu ada disini (beliau sambil menunjuk dadanya 3 kali). Cukuplah seseorang dikatakan jahat jika ia menghina saudaranya sesama muslim. Haram bagi seorang muslim dari muslim yang lainnya, darahnya, hartanya, dan harga dirinya" (HR. Muslim) ${ }^{41}$ Kedudukan Hadis Hadis ini sangat penting karena merupakan landasan dalam

\footnotetext{
${ }^{39}$ Sunan Tirmidzi No Hadist 1887/3891

${ }^{40}$ Bulughul marom No. hadist 1508/1597

${ }^{41}$ Arbain An-Nawawi No. hadist 35/42
} 
bermuamalah dengan sesama muslim dan menunaikan hak-hak mereka. hasad, Najas, Kebencian dan Boikot hasad adalah tidak suka melihat saudaranya mendapat kenikmatan, baik berangan-angan hilangnya nikmat tersebut dari saudaranya atau tidak. hasad merupakan akhlak yang sangat tercela. hasad di samping wujud protes terhadap takdir, juga su'udzon kepada Alloh tatkala menganggap bahwa nikmat tersebut tidak pantas didapat saudaranya. Najas adalah bermuamalah dengan melakukan berbagai macam tipu daya. Najas hukumnya haram karena semestinya bermuamalah dengan saudaranya dengan muamalah yang baik. Kebencian kepada saudaranya ada dua bentuk, yaitu: Benci karena agama. Kebencian seperti ini boleh bahkan wajib, yaitu membenci saudaranya karena kejelekan agamanya. Kebencian seperti ini tidaklah kebencian secara mutlak, dalam arti di samping rasa benci terdapat juga dalam hatinya rasa cinta karena masih saudaranya. Benci karena dunia. Kebencian seperti ini haram hukumnya. Maka jika seseorang mendapatkan dalam dirinya kebencian kepada saudaranya hendaklah dia melihat kepada kebaikannya agar kebencian tersebut hilang. ${ }^{42}$

\section{Kesimpulan}

Dalam kamus besar Bahasa Indonesia. Kata Akhlak diartikan sebagai budi pekerti atau kelakuan. Kata akhlak walaupum terambil dari Bahasa arab (yang bisa berartikan tabiat, kebiasaan, bahkan agama), namun kata seperti itu tidak di temukan dalam Al-Quran.

Pembinaan akhlak merupakan tumpuan perhatian pertama dalam islam. Karena begitu pentingnya akhlak bagi kehidupan umat manusia, oleh karena itu Allah SWT.

Metode uswah, yaitu sesuatu yang pantas untuk di ikuti,karena mengandung nilai-nilai kemanusiaan.

Metode Ta'widiyah (pembiasaan). Secara etimologi pembiasaan asal katanya adalah biasa. Dalam kamus umum bahasa indonesia, biasa artinya lazim atau umum; seperti sedia kala, sudah merupakan hal yang tidak terpisahkan dalam kehidupan sehari-hari.

${ }^{42}$ https://carihadis.com/Arbain_Nawawi_I/=hasad 
Perilaku tercela adalah sifat yang sangat merugikan diri sendiri maupun orang lain, dalam ajaran Islam perbuatan tersebut sangat bertentangan.

Ananiyah ini adalah karakter alami yang ada pada diri setiap insan apabila ia diperlakukan sesuai dengan batas koridor yang ada.

Ghadab harfiah berarti "marah" atau "pemarah", atau disebut juga dengan temperamental. Ghadab dalam arti pemarah merupakan salah satu sifat negatif. Bila ditinjau definisi marah merupakan suatu reaksi terhadap hambatan yang menjadi sebab gagalnya suatu usaha atau suatu perbuatan dalam mencapai suatu tujuan tertentu.

Ghibah menurut bahasa berarti umpatan, fitnah dan gunjingan. Kemudian kata "umpatan" dalam kamus bahasa Indonesia dapat diartikan sebagai perkataan yang memburuk-burukkan orang lain. Dapat pula diartikan penggunjingan yang diidentikkan dengan kata gosip, yaitu kata negatif tentang seseorang. Gibah diidentikkan dengan umpatan, pergunjingan dan gosip. Ghibah adalah bahasa Arab dan telah populer di kalangan masyarakat muslim Indonesia.

\section{DAFTAR PUSTAKA}

Kamus Besar Bahasa Indonesia,

Hidayati,Heny Narendrany, Pengukuran akhlakul karimah mahasiswa, Syarif hidayatullah

Jakarta, Jakarta, 2009

Ahmad, Imam S, Tuntunan Akhlakul Karimah, Lekdis, Jakarta, 2005

Zulkifli,MA Pengantar Studi Islam, Bias cemerlang, Tangerang, 2006.

Zuhairi, Dkk. 1983. Metodik khusus Pendidikan agama. Surabaya : Usaha nasional

Khalîl Ibn Ahmad, Kitâb al-'Ain, Tahqîq: 'Abd al-Hamîd Hindâwî, Juz 1, (Beirut: Dâr alKutub al-'Ilmiyah, 2003),

Ibn Mandzur, Lisân al-‘Arab, (Kairo: Dâr al-Ma’ârif, t.t.), 
Abû Hâmid al-Ghazâlî, Ihyâ' 'Ulûm ad-Dîn, Tahquîq: Asy-Syahât ath-Thahân dan 'Abdullâh alMinsyâwî, Jilid 3, (Manshûrah: Maktabah al-Îmân, 1996)

Ahmad Warson Munawir, al-Munawwir; Kamus Arab Indonesia (Cet. IV; Yogyakarta: pustaka rogressif, 1997),

WJS. Poerwadarminta, Kamus Umum Bahasa Indonesia (Cet. VII; Jakarta: PN. Balai Pustaka, 1985)

Abu al-Husein Ahmad ibn Faris ibn Zakariya, Mu'jam Maqayis al-Lugah (Cet. I; Beirut: Dar al Fikr, 1994)

Jamal al-Din Muhammad ibn Makram al-Mansur, Lisan al-'Arab, jilid 5 (Cairo: Dar alMa'arif, t.th.),

Wahbah Az-Zuhaili, Ensiklopedia Akhlak Muslim: Berakhlak dalam Bermasyarakat, (Jakarta:

.Mizan Publika , 2014),

kitab Ash-Shahihah (286). (Bukhari, 78-Kitab Al Adab, 39- Bab Husnul khuluqi was-sakha'i wa ma yakrahu minal-bukhli. Muslim, 4- Kitab Fadha^il, 16-Katsratu-hayatihi shallallahu 'alaihi wasallam, hadis 68).

kitab Ash-Shahihah

Kitab Bulughul marom

Musnad ahmad

Mustadrak Hakim

Sunan Tirmidzi

Arbain An-Nawawi

https://carihadis.com/Shahih_Adabul_Mufrad_Terjemah/=menyempurnakan\%20akhlak

https://carihadis.com/Arbain_Nawawi_II/=AKHLAK\%20TERCELA

https://carihadis.com/Arbain_Nawawi_I/=hasad 